\title{
PENGARUH SEDIMEN TERHADAP UMUR LAYANAN PADA TAMPUNGAN MATI (DEAD STORAGE) WADUK KRISAK DI WONOGIRI DENGAN METODE USLE (UNIVERSAL SOIL LOSSES EQUATION)
}

\author{
Fakhrizal Arifandi ${ }^{1}$, Dr. Cahyono Ikhsan, ST, MT. ${ }^{2}$ ) \\ ${ }^{1)}$ Pengajar Fakultas Teknik, Prodi Teknik Sipil, Universitas Sebelas Maret \\ ${ }^{2)}$ Mahasiswa Fakultas Teknik, Prodi Teknik Sipil, Universitas Sebelas Maret \\ Jalan Ir. Sutami No.36A Surakarta 57126.Telp.0271647069. Email: fakhrizala@gmail.com
}

\begin{abstract}
Problem in dam management is sedimentation. Sediment was caused by erosion, sediment load would settle in the dam and the dead storage capacity of dam would decrease. After that useful life of dam would be decreases. Watershed of Bengawan Solo is one of watershed in Indonesia that requires immediate treatment (Joko Sutrisno, 2011). That condition of the river basin is concerned, especially the magnitude of the rate of erosion is high enough and the assessed land productivity decreases. Such conditions occur both upstream and downstream areas. Jlantah watershed located at the mouth of the Jlantah River near water points (intake) of dams. Sedimentation accounted for the largest assessed to be very disturbing reservoir operations. In addition to causing sedimentation, erosion will also cause a reduction in the thickness of the soil (solum) and reduced soil fertility levels in the upstream region. The purpose of this study is to get the influence of sediments on the age of service in dead storage using USLE prediction method. This study uses quantitative and descriptive methods can be divided into 3 stages of implementation as follows: data collection, data analysis, conclusions and suggestions. The data used in the form of rainfall data for 10 years between 2009 until 2018. The map used is Soil Map, Topography and Land Use Map. Data collected through literature study and using data from the Forestry Technology Research Center of Watershed Management Surakarta, Associate of Bengawan Solo River Region and Jasa Tirta Wonogiri. The result of analysis according to USLE formula in erosion prediction, there was 2,437,833.4990 ton/years with the volume on the sediment storage of Krisak. dam, which is 816,147.8068 m3/year and the dam service of 4.6 ages in dead storage.
\end{abstract}

Keywords: USLE, Useful Life, Dam, Erosion, Sediment.

\begin{abstract}
ABSTRAK
Salah satu masalah dalam pengelolaan waduk adalah sedimentasi. Sedimen diakibatkan dari erosi, angkutan sedimen bertambah maka sedimen akan mengendap di dalam waduk dan kapasitas tampungan mati waduk akan berkurang. Kemudian umur waduk tersebut akan mengalami percepatan pengurangan layanannya. Daerah Aliran Sungai (DAS) Bengawan Solo merupakan salah satu DAS di Indonesia yang segera memerlukan penanganan (Joko Sutrisno, 2011). Kondisi daerah aliran sungainya Bengawan Solo sudah memprihatinkan, terutama besarnya laju erosi yang cukup tinggi serta produktivitas lahan yang dinilai semakin menurun. SUB-DAS Jlantah yang berlokasi di muara Sungai Krisak berada di dekat tempat pengambilan air Waduk Krisak, dinilai menyumbang sedimentasi terbesar yang akan sangat mengganggu operasional waduk. Selain menyebabkan sedimentasi, erosi juga akan menyebabkan berkurangnya ketebalan tanah dan berkurangnya tingkat kesuburan tanah di wilayah hulu. Tujuan dari penelitian ini adalah mendapatkan pengaruh sedimen terhadap umur waduk pada tampungan mati menggunakan metode USLE. Metode penelitian ini menggunakan metode deskriptif kuantitatif dan secara garis besar dibagi menjadi 3 tahapan pelaksanaan sebagai berikut : pengumpulan data, analisa data, kesimpulan dan saran. Data yang digunakan berupa data curah hujan jangka waktu 10 tahun antara tahun 2009 sampai 2018. Peta yang digunakan adalah Peta Tanah, Peta Topografi dan Peta Tata Guna Lahan. Pengumpulan data dilakukan melalui studi literatur serta menggunakan data yang dimiliki Balai Penelitian Teknologi Kehutanan Pengelolaan Daerah Aliran Sungai Surakarta, Balai Besar Wilayah Sungai Begawan Solo dan Jasa Tirta Wonogiri. Hasil analisis berdasarkan prediksi erosi USLE diperoleh 2.437.833,4990 ton/tahun dengan volume yang masuk pada tampungan sedimen Waduk Krisak yaitu 816.147,8068 m3/tahun dengan umur layanan 4,6 tahun.
\end{abstract}




\section{Kata kunci: USLE, Umur Layanan, Waduk, Erosi, Sedimen PENDAHULUAN}

\section{Latar Belakang}

Di Kabupaten Wonogiri selain Waduk Gajah Mungkur juga terdapat beberapa waduk yang tersebar di berbagai tempat, salah satu diantaranya adalah Waduk Krisak. Waduk Krisak dibangun pada tahun 1943. Waduk Krisak terletak \pm 10 Km dari Kota Wonogiri, tepatnya di Desa Pare, Kecamatan Selogiri, Kabupaten Wonogiri. Fungsi utama Waduk Krisak untuk pengendali banjir, memenuhi kebutuhan irigasi yang mencakup wilayah seluas $274 \mathrm{Ha}$, serta sebagai tempat pariwisata. Berdasar perencanaan, volume tampungan Waduk Krisak terbagi atas volume normal sebesar 3,72 juta m3, volume minimum sebesar 1,03 juta m3, serta volume efektif sebesar 2,69 juta m3.

Waduk Krisak dibangun pada tahun 1943 dengan rencana usia efektif waduk yaitu \pm 50 tahun. Perencanaan volume tampungan Waduk Krisak terbagi atas volume normal sebesar 3,72 juta m3, volume minimum sebesar 1,03 juta m3, serta volume efektif sebesar 2,69 juta m3. Namun, daya tampung air di Waduk Krisak saat ini menurun drastis. Salah satu faktor yang mempengaruhi adalah kapasitas waduk yang semakin berkurang akibat adanya sedimentasi. Bila tidak dilakukan penanggulangan masalah sedimentasi di Waduk Krisak maka akibatnya sedimen akan mengendap di dasar waduk dan kapasitas tampungan mati (dead storage) waduk akan mengalami penyusutan. Demikian juga dengan umur waduk tersebut akan mengalami percepatan pengurangan layanannya.

Terdapat berbagai metode untuk mencari prediksi laju eorsi untuk mengetahui besarnya sedimen yang mengendap pada tubuh waduk. Dalam penelitian ini peneliti menggunakan metode USLE (Universal Soil Loss Equation) untuk mengetahui prediksi laju erosi. Metode ini digunakan karena metode ini dirancang untuk memprediksi laju erosi dalam jangka waktu yang panjang dengan memperhitungkan faktor sistem pertanian dan pengelolaan lahan. Faktor tanaman dan pengelolaan lahan merupakan salah satu faktor yang mengakibatkan besar kecilnya erosi. Selain itu, metode ini sederhana dan digunakan secara umum serta dapat diterima.

Pada tahun 2013 pemerintah melalui Balai Besar Wilayah Sungai Bengawan Solo melaksanakan rehabilitasi untuk memperpanjang umur serta fungsi waduk. Berdasarkan hal tersebut, diperlukan penelitian lebih lanjut untuk mengetahui umur layanan waduk berdasarkan besarnya erosi dengn metode USLE pada Waduk Krisak setelah dilakukan rehabilitasi, yang kemudian diketahui sedimen tahanan pada waduk untuk digunakan menghitung sisa umur efektif Waduk Krisak di Kabupaten Wonogiri.

\section{TINJAUAN PUSTAKA}

Waduk merupakan bangunan air yang berfungsi untuk menampung air yang digunakan saat debit rendah. Fungsi waduk itu antara lain sebagai irigasi, pembangkit listrik dan pengendalian banjir (Sudjarwadi, 1989). Beberapa permasalahan yang terjadi pada waduk adalah aspek gelombang di permukaan air yang timbul akibat tiupan angin yang perlu dipertimbangkan terhadap kestabilan struktur waduk, adanya rembesan dan aspek laju sedimentasi (Sudjarwadi, 1989). Aspek laju sedimentasi akibat erosi yang terjadi di hulu DAS yang terbawa oleh air melalui sungai menuju hilir atau waduk, kemudian mengendap ke dalam volume tampungan mati waduk.

Frevert et al (1963) menjelaskan bahwa erosi tanah didefinisikan sebagai kehilangan tanah lebih cepat dari proses erosi geologi. Besarnya laju kehilangan tanah (erosi) bervariasi terhadap kemiringan lereng, panjang lereng dan intensitas hujan. Semakin besar kemiringan lereng, panjang lereng dan intensitas hujan semakin besar erosi. Sedimentasi merupakan proses lanjutan dari peristiwa erosi. Tanah tersebut mengalir melalui cekungan-cekungan atau saluran air kemudian masuk ke sungai. Sungai selain berfungsi sebagai sarana mengalirkan air juga berfungsi sebagai pengangkut bahan bahan material yang dapat berupa sedimen (Qohar, 2002).

Metode Universal Soil Loss Equation (USLE) merupakan metode umum digunakan untuk memprediksi laju erosi. Selain sederhana metode ini baik digunakan didaerah yang faktor utama penyebab erosinya adalah hujan dan aliran permukaan (Arsyad, 1989). 
Analisa umur waduk dihitung dengan hubungan antara volume sedimen yang mengendap dengan sisa volume dead storage (volume tampungan mati) waduk (Lewis et al, 2013).

\section{LANDASAN TEORI}

\section{Daerah Aliran Sungai}

Daerah Aliran Sungai (DAS) adalah daerah dimana setiap air hujan yang jatuh ke suatu kawasan bermuara ke dalam satu alur sungai. DAS mempunyai karakteristik spesifik yang berkaitan erat dengan unsur utamanya seperti jenis tanah, tata guna lahan, topografi, kemiringan dan panjang lereng dilihat dari sistem hidrologi. Karakteristik biofisik DAS tersebut dalam merespon curah hujan yang jatuh di wilayah DAS dapat memberikan pengaruh terhadap besar kecilnya evapotranspirasi, infiltrasi, perkolasi, air larian, aliran permukaan, kandungan air tanah, dan aliran sungai.s.

\section{Erosi}

Erosi merupakan proses terkelupasnya butiran tanah dari induknya dan terangkutnya material tersebut oleh air atau angin. Erosi kulit (sheet erosion) adalah erosi yang terjadi ketika lapisan tipis permukaan tanah di daerah berlereng terkikis oleh kombinasi air hujan dan air larian (run off).

Kebanyakan model yang dipakai untuk studi erosi adalah model parametrik kotak kelabu (Suripin, 2001). Model ini menjembatani gap antara model kotak putih dan model kotak hitam. Model ini antara lain:

a. Model Regressi Ganda (Multiple Regression)

b. Universal Soil Loss Equation (USLE)

c. Modifikasi USLE (MUSLE)

\section{Sedimentasi}

Sedimen adalah agregat-agregat butiran hasil erosi lahan yang terkumpul dibeberapa tempat yang telah dipindahkan pada jarak tertentu, baik lateral maupun vertical (Vanoni, 1975). Sedangkan proses sedimentasi adalah pelepasan, pengangkutan dan pengendapan tanah yang tererosi (Overbeek, HJ, 1978).

\section{Perkiraan Erosi Metode USLE (Universal Soil Loss Equation)}

Dari beberapa metode untuk memprakirakan besarnya erosi permukaan, metode USLE yang dikembangkan oleh Wischmeir dan Smith (1978) adalah metode yang paling umum digunakan untuk memprakirakan besarnya erosi (Chay Asdak, 2002).

Langkah-langkah menentukan perkiraan erosi metode USLE adalah sebagai berikut:

1) Faktor Erosivitas Hujan (R)

Perhitunngan erosivitas hujan ditunjukkan pada rumus berikut

$$
\text { EI30 }=6,12 \mathrm{~Pb}^{1,21} \mathrm{~N}^{-0,47} \operatorname{Pmax}^{0,53}
$$

Dengan:

$$
\begin{array}{ll}
\mathrm{EI} 30 & =\text { Indeks erosivitas hujan (ton.cm } / \mathrm{jam}) \\
\mathrm{Pb} & =\text { Curah hujan bulanan } \\
\mathrm{N} & =\text { Jumlah hari hujan bulanan } \\
\mathrm{Pmax} & =\text { Hujan maksimum }
\end{array}
$$

2) Faktor Erodibilitas Tanah $(\mathrm{K})$

Faktor erodibilitas tanah $(\mathrm{K})$ menunjukan resistensi partikel tanah terhadap pengelupasan dan transportasi partikelpartikel tanah tersebut oleh adanya energi kinetik air hujan. Berikut ini adalah beberapa angka erodibilitas menurut jenis tanahnya.

3) Faktor Panjang Lereng dan Kemiringan Lereng (LS)

Nilai faktor LS (panjang dan kemiringan) dapat dihitung dengan menggunakan rumus

Untuk kemiringan lereng lebih kecil $20 \%$ :

$$
\mathrm{LS}=\mathrm{L} / 100\left(0,76+0,53+0,076 \mathrm{~S}^{2}\right)
$$

Untuk kemiringan lereng lebih besar dari $20 \%$ : 


$$
\mathrm{LS}=(\mathrm{L} / 22.1)^{0.6} \mathrm{x}(\mathrm{s} / 9)^{1.4}
$$

Dengan:

$\mathrm{L}=$ panjang lereng $(\mathrm{m})$

$\mathrm{S}=$ kemiringan lereng $(\%)$

4) Faktor Pengelolaan Tanaman (C)

Faktor pengelolaan tanaman adalah faktor yang nenunjukkan keseluruhan pengaruh dari vegetasi, seresah, keadaan permukaan tanah, dan pengelolaan lahan terhadap besarnya tanah yang hilang (erosi). Oleh karena itu besarnya angka $\mathrm{C}$ tidak selalu sama dalam kurun waktu satu tahun.

5) Faktor Indeks Pengelolan dan Konservasi Tanah (P)

Faktor $\mathrm{P}$ adalah nisbah antara tanah tererosi rata-rata dari lahan yang mendapat perlakuan konservasi tertentu terhadap tanah tererosi rata-rata dari lahan yang diolah tanpa tindakan konservasi, dengan catatan faktor-faktor penyebab erosi yang lain tidak berubah nilainya.

6) Perhitungan SDR (Sedimen Delivery Ratio)

Nilai SDR ini tergantung dari luas DAS, yang erat hubungannya dengan pola penggunaan lahan. Hal itu dapat dirumuskan dalam suatu hubungan fungsional, Menurut Weischmeier dan Smith (1958) yaitu sebagai berikut

$$
\mathrm{SDR}=\frac{\mathrm{S}\left(1-0,8683 A^{-0,2018}\right)}{2(\mathrm{~S}+50 n)}+0,08683 A^{-0,2018} \text {. }
$$

Dengan:

$$
\begin{array}{ll}
\mathrm{SDR} & =\text { Nisbah Pelepasan Sedimen, nilainya } 0<\mathrm{SDR}<1 \\
\mathrm{~A} & =\text { Luas DPS }(\mathrm{Ha}) \\
\mathrm{S} & =\text { Kemiringan lereng rataan permukaan DAS }(\%) \\
\mathrm{n} & =\text { koefisien kekasaran manning }
\end{array}
$$

7) Laju Erosi Potensial

Erosi potensial adalah erosi maksimum yang mungkin terjadi di suatu tempat dengan keadaan permukaan tanah gundul sempurna sehingga terjadinya proses erosi hanya disebabkan oleh faktor alam (tanpa adanya keterlibatan manusia maupun faktor penutup permukaan tanah, seperti tumbuhan dan sebagainya), yaitu iklim, khususnya curah hujan, sifat-sifat internal tanah, dan keadaan topografi tanah. Pendugaan erosi potensial dapat dihitung dengan pendekatan rumus sebagai berikut

Epot $=R \times K \times L S \times A$

Dengan:

E-pot $=$ Erosi potensial (ton/tahun)

$\mathrm{R}=$ Indeks erosivitas hujan

$\mathrm{K} \quad=$ Erodibilitas tanah

LS $\quad=$ Faktor panjang dan kemiringan lereng

A $\quad=$ Luas daerah aliran sungai $\left(\mathrm{km}^{2}\right)$

8) Laju Erosi Aktual

Erosi aktual terjadi karena adanya campur tangan manusia dalam kegiatannya sehari-hari, misalnya pengolahan tanah untuk pertanian dan adanya unsur-unsur penutup tanah, baik yang tumbuh secara alamiah maupun yang dibudidayakan oleh manusia. Dengan demikian bisa disimpulkan bahwa erosi aktual adalah hasil ganda antara erosi potensial dengan pola penggunaan lahan tertentu, sehingga dapat dihitung dengan rumus berikut (Weischmeier dan Smith, 1958):

$\mathrm{E}-\mathrm{Akt}=\mathrm{E}-\mathrm{pot} \times \mathrm{CP}$

Dengan:

E-Akt $=$ Erosi aktual di DAS (ton $\left./ \mathrm{km}^{2} / \mathrm{th}\right)$

E-pot $=$ Erosi potensial $\left(\right.$ ton $\left./ \mathrm{km}^{2} / \mathrm{th}\right)$

$\mathrm{CP}=$ Faktor tanaman dan pengawetan tanah

9) Laju Sedimen Potensial

e-Jurnal MATRIKS TEKNIK SIPIL/ Desember 2019/433 
Dalam penelitian ini nilai SDR yang dipakai menggunakan metode Weischmeier dan Smith (1958) pendugaan laju sedimen potensial yang terjadi di suatu DAS dihitung dengan persamaan Weischmeier dan Smith, sebagai berikut:

S-pot $=$ E-Akt x SDR

Dengan:

SDR = Sediment Delivery Ratio

S-pot $=$ Sedimentasi potensial

E-Akt $=$ Erosi aktual

\section{Prediksi Umur Layanan (Useful Life) Waduk}

Usia atau Umur waduk adalah waktu yang diperlukan endapan mengisi semua volume tampungan mati (Dead Storage) sampai saat intake tertutup endapan. Batas usia umur waduk ditentukan oleh habisnya manfaat waduk untuk bisa diatur penggunaannya bagi kepentingan pengairan atau pembangkit tenaga listrik, dimana air keluaran melalui intake. Di dalam perencanaan pembuatan waduk diadakan pembagian ruang dalam volume waduknya, yaitu bagian volume yang airnya dapat atau tidak dapat diatur melaui suatu pintu pengatur air. Volume diatas bidang horisontal melaui intake merupakan volume Life Storage, sedangkan volume di bawahnya disebut Tampungan Mati atau Kantong Lumpur (Dead Storage) (Asban Basiran, dkk, 2014).

Sisa umur waduk dihitung melalui besarnya rata-rata masukan sedimen ke waduk dikurangi pengeluaran sedimen dalam satu tahun, kemudian dikalikan jumlah tahun operasi waduk sehingga diketahui volume sediment yield saat ini. Volume sediment yield dihubungkan dengan rencana umur waduk yang diperkirakan ketika akan membangun waduk. Berat sediment yield dari tiap aliran sungai dalam satuan ton dirubah terlebih dahulu menjadi satuan volume $\left(\mathrm{m}^{3}\right)$, yaitu membaginya dengan berat jenis sedimen aliran sungai bersangkutan. Besarnya berat jenis sedimen dari tiap aliran di DAS bagian hulu dengan persamaan berikut:

$$
\text { Volume }=\frac{\text { hasil perhitungan sedimen }}{\text { berat jenis }}
$$

Dari hasil perhitungan data diatas akan diperoleh perkiraan sisa umur waduk, dengan besar kapasitas volume tampungan mati waduk dengan volume sedimen yang masuk ke tampungan mati waduk dalam satu tahun yan dirumuskan oleh persamaan berikut:

Umur Waduk $=\frac{\text { kapasitas dead storage }}{\text { volume sedimen tahanan }}$

Dengan:

Umur efektif waduk diketahui dari jumlah sedimen yang menutupi daya tampungan mati (dead storage) yang dihitung melalui besarnya kapasitas volume waduk dibagi volume sedimen yang masuk ke waduk.

\section{METODOLOGI PENELITIAN}

Langkah Analisis

Langkah-langkah penyusunan Skripsi ini adalah:

1) Pengumpulan data

Data-data yang diperoleh adalah data curah hujan, Peta Tanah, Peta Topografi dan Peta Tata Guna Lahan.

2) Pengolahan Data

Urutan pengolahan data yang dilakukan adalah:

a. Analisis hidrologi (analisis data curah hujan)

b. Perhitungan laju erosi dengan metode USLE.

c. Perhitungan umur efektif Kaduk Krisak.

HASIL DAN PEMBAHASAN

Faktor Erosivitas Hujan (R) 
Data Hujan yang diperoleh dari Balai Besar Wilayah Sungai Bengawan Solo berupa curah hujan harian tahun 2009 sampai dengan tahun 2018. angka rata-rata faktor $\mathrm{R}$ dihitung dari data curah hujan tahunan sebanyak mungkin. Data curah hujan harian diolah sehingga didapat curah hujan bulanan, jumlah hari hujan tiap bulan, dan curah hujan harian maksimum, sehingga didapat nilai erosivitas bulanan yang kemudian diakumulasi menjadi erosivitas tahunan. Berikut merupakan hasil perhitungan erosivitas hujan tahunan dengan menggunakan persamaan 1 yang dapat dilihat pada Tabel 1. 
Tabel 1 Erosivitas Tahunan

\begin{tabular}{ccc}
\hline Tahun & $\begin{array}{c}\text { Rata rata Erosivitas } \\
\text { Tahunan }\end{array}$ & $\begin{array}{c}\text { Erosivitas Total } \\
\text { Ton.mm/jam }\end{array}$ \\
\hline \hline 2009 & 10536,69356 & \\
\hline 2010 & 11733,86746 & \\
\hline 2011 & 7425,789151 & \\
\hline 2012 & 6637,986507 & \multirow{2}{*}{51071,27} \\
\hline 2013 & 4165,240369 & \\
\hline 2014 & 3387,252971 & \\
\hline 2015 & 742,6216248 & \\
\hline 2016 & 443,746813 & \\
\hline 2017 & 2303,132999 & \\
\hline 2018 & 1990,077254 & \\
\hline
\end{tabular}

Berdasarkan Tabel 1 diperoleh nilai erosivitas hujan (R) sebesar 51071,27 ton.mm/jam atau 510,7127 ton.cm/jam.

\section{Erodibilitas Tanah (K)}

Jenis tanah di SUB-DAS Jlantah bervariatif, diantranya yaitu tanah Andosol yaitu tanah yang berasal dari induk abu vulkanik, Latosol yaitu tanah yang berasal dari batuan gunung api dan mengalami pelapukan, Litosol yaitu tanah yang berasal dari batuan keras yang mengalami pelapukan, Grumosol yaitu tanah yang berasal dari batuan kapur dan lempung, serta Mediteran yaitu tanah yang berasal dari batuan kapur keras. Dari berbagai jenis tanah tersebut didapatkan nilai $\mathrm{K}$ yaitu 0,24 .

\section{Faktor Panjang dan Kemiringan Lereng (LS)}

Panjang kereng SUB-DAS Jlantah diketahui yaitu $13 \mathrm{~km}$ dengan kemiringan 8,71\%. Dari data tersebut dapat dihitung menggunakan Persamaan 2 dan mendapatkan nilai LS yaitu 2633,0715 m.

Faktor Pengolahan Tanaman (C) dan Praktek Konservasi Tanah (P)

Hasil analisis nilai C dan P untuk masing-masing tata guna lahan pada SUB-DAS Jlantah dapat dilihat pada Tabel 2 berikut ini:

Table 2 Hasil Analisis Nilai C dan P

\begin{tabular}{ccc}
\hline Tata Guna Lahan & $\mathbf{C}$ & $\mathbf{P}$ \\
\hline \hline Tegalan & 0,45 & 0,25 \\
\hline Sawah & 0,05 & 0,35 \\
\hline Perkampungan & 0,3 & 0,15 \\
\hline Semak Belukar & 0,45 & 0,25 \\
\hline Hutan & 0,02 & 0,6 \\
\hline Rata-rata & 0,254 & 0,32 \\
\hline
\end{tabular}

\section{Laju Erosi Potensial}

Laju erosi potensial dapat dinyatakan sebagai hasil ganda antara faktor-faktor curah hujan, erodibilitas tanah, dan topografi (kemiringan dan panjang lereng). SUB-DAS Jlantah mempunyai luas area $54,5 \mathrm{~km}^{2}$ dan dari perhitungan di atas telah didapatkan nilai $\mathrm{R}$ yaitu 510,7127 ton.cm/jam, nilai $\mathrm{K}$ yaitu 0,24 serta nilai LS sebesar 2633,0715 m. Dari data diatas dapat dihitung dengan Persamaan 5 dan mendapatkan nilai Epot yaitu 17344943,1 ton $/ \mathrm{km}^{2} /$ tahun. 


\section{Laju Erosi Aktual}

Laju erosi aktual adalah hasil antara laju erosi potensial dengan pola penggunaan lahan pada SUB-DAS Jlantah. Daerah tangkapan air terdiri dari beberapa klasifikasi penggunaan lahan. Untuk data lengkapnya ditampilkan pada Tabel 2.

Tabel 3. Perhitungan Laju Erosi Aktual Tata Guna Lahan SUD-DAS Jlantah

Tabel 3 Perhitungan Laju Erosi Aktual

\begin{tabular}{ccccc}
\hline Tata Guna Lahan & Ep & C & P & Ea \\
\hline \hline Tegalan & 17344943,1 & 0,45 & 0,25 & 1951306,098 \\
\hline Sawah & 17344943,1 & 0,05 & 0,35 & 303536,5042 \\
\hline Perkampungan & 17344943,1 & 0,30 & 0,15 & 780522,4393 \\
\hline Semak Belukar & 17344943,1 & 0,45 & 0,25 & 1951306,098 \\
\hline Hutan & 17344943,1 & 0,02 & 0,60 & 208139,3171 \\
\hline & $\Sigma$ & & & 5194810,4572 \\
\hline
\end{tabular}

Dari tabel di atas didapatkan jumlah laju erosi actual pada SUB-DAS Jlantah, yaitu sebesar 5.194.810,4572 ton $/ \mathrm{km}^{2} /$ tahun.

\section{Laju Sedimen}

Hasil laju sedimen tergantung dari berarnya erosi di daerah tangkapan dan besarnya laju erosi. Cara menentukan besarnya hasil laju sadimen yaitu dengan menghitung besarnya SDR (Sediment Delivery Ratio) suatu daerah tangkapan air. Nilai SDR ini tergantung dari luas DAS, yang erat hubungannya dengan pola penggunaan lahan. Dari Persamaan 4 dan Persamaan 5 didapatkan laju sedimen pada SUB-DAS Jlantah yaitu sebesar 2.437.833,4990 ton/tahun.

\section{Umur Layanan Waduk Krisak}

Kapasitas tampungan waduk Krisak pada elevasi muka air $+113,5 \mathrm{~m}$ (dead storage) yaitu $3.742 .089 \mathrm{~m} 3$ (Dinas PSDA Balai Besar Wilayah Sungai Bengawan Solo, 2016). Diketahui bahwa nilai berat jenis tanah pada wilayah waduk Krisak yaitu sebesar 2,987 ton $/ \mathrm{m}^{3}$, maka nilai volume sedimen dapat dihitung dengan Persamaan 8 dan mengahsilkan volume sedimen yang masuk yaitu $816147,8068 \mathrm{~m}^{3} /$ tahun.

Setelah diketahui volume sedimen pada waduk Krisak selanjutnya dapat menghitung sisa umur layanan waduk dengan Persamaan 9 dan didapatkan sisa umur layanan waduk yaitu 4,6 tahun.

\section{KESIMPULAN}

Dari hasil analisis dan pembahasan pada bab sebelumnya, maka dapat diambil kesimpulan antara lain:

1. Dengan perhitungan prediksi erosi metode USLE didapatkan laju erosi sebesar $5.194 .810,4572 \mathrm{ton} / \mathrm{km}^{2} / \mathrm{tahun}$, laju sedimen sebesar 2.437.833,4990 ton/tahun, dan volume sedimen sebesar 816.147,8068 m³/tahun.

2. Setelah rehabilitasi yang dilaksanakan pada tahun 2013, melalui perhitungan prediksi erosi metode USLE dapat diketahui sisa umur efektif Waduk Krisak di Kabupaten Wonogiri adalah 4,6 tahun. 


\section{SARAN}

Berdasarkan penelitian yang telah dilaksanakan penulis memberikan saran untuk yang berguna studi selanjutnya sebagai berikut:

1. A.Dalam penleitian ini penulis mempersepsikan bahwa semua hasil perhitungan sedimen akan masuk dan tertahan di dalam tubuh waduk. Tetapi, pada kenyataannya tidak sepenuhnya sesuai dengan pengendapan yang terjadi karena adanya reduksi yang terjadi saat proses angkutan sedimen dari daerah aliran sungai sampai masuk dan tertahan pada tubuh waduk. Oleh sebab itu evaluasi menggunakan metode trap efficiency sedimen diperlukan untuk penelitian selanjutnya.

2. Mengingat besarnya angkutan sedimen akibat erosi di daerah tangkapan Waduk Krisak, upaya penambahan umur layanan waduk dapat dilakukan dengan beberapa alternatif, salah satunya dengan dengan cara merubah pola penanaman vegetasi.

3. Melakukan rehabilitasi pada waduk Krisak untuk mengurangi sedimen yang mengendap.

\section{REFERENSI}

Asdak, Chay. 2002. Hidrologi dan Pengelolaan Tanah Daerah Aliran Sungai. UGM Press. Yogyakarta.

Arsyad S. 1989. Konservasi Tanah dan Air. IPB Press. Bogor.

Basiran, Asban dkk. Perbitungan Usia Manfaat Waduk Ir. H. Juanda. Purwakarta.

Frevert, R.K., G.O. Schwab, T.W. Edminster, and K.K. Barness. 1963. Soil and Water Conservation Engineering (Third Edition). John Wiley and Son Inc. New York.

Lewis S.E., Cbainbridge Z.T., Kunhert P.M., Sherman B.S., Henderson B., Dougall C., Cooper M., Brodie J.E. 2013. Calculating Sediment Trapping Efficiencies for Reservoir in Tropical Setting: A Case Study Frim The Burdekin Falls Dam, NE Australia. Water Resources Research Vol. 49.

Overbeek, H.J. 1978. River Engineering and Flood Protection. AIT. Bangkok.

Qohar, Abdul. 2002. Prediksi Umur Layaan Waduk Kedungombo Akibat Sedimen. Tugas Akhir Fakultas Teknik Universitas Gadjah Mada, Yogyakarta.

Sudjarwadi. 1989. Teknik Sumberdaya Air. KMTS-UGM. Yogyakarta.

Suripin. 2001. Pelestarian Sumber Daya Tanah dan Air. Idea Dharma. Bandung.

Sutrisno, Joko. 2011. Prediksi Erosi dan Sedimentasi di Sub Daerah Aliran Sungai Keduang Kabupaten Wonogiri. Institut Pertanian Bogor.

Vanoni, V.A. 1975. Sedimentation Engineering Practice. American Society of Civil Engineering. New York.

Wischmeier, W. H., and Smith L. D. (1978). Predicting Rainfall-Erosion Losses : A Guide To Conservation Planning. USDA Agriculture Handbook. 